\title{
HPS FOR BEGINNER/HPS FOR INTERMEDIATE
}

\section{島崎康司*}

\begin{abstract}
[要旨 $]$ 近年, 医学教育の変化による, 卒前教育の改革, 卒後臨床研修の必修化によっ て，シミュレータを用いた教育が重要な位置を占めるようになってきた．ここでは麻 酔科領域でいち早く実用化された高機能患者シミュレータについて理解を深めていた だくことを目的とした. HPS FOR BEGINNERでは，患者シミュレータを使用した ことがない方を対象に，METI社製のHPS/ECS 等のシミュレータを中心に，開発 の歴史, ハードおよびソフトウェアの特徵, 設置スペースなどの紹介をする. HPS FOR INTERMEDIATEでは, HPS FOR BEGINNER を受けて，患者シミュレータ の使用について，患者作成やシナリオ作成，シミュレーション方法について紹介をする. キーワード：HPS, ECS, 生理学・薬理学モデル制御
\end{abstract}

(日臨麻会誌Vol.24 No.7, 299 309, 2004)

\section{HPS FOR BEGINNER}

卒後臨床研修や学生教育などを含めた医学教育の 改革や，医療事故などの表面化による社会的な医学 分野への関心が集まるという時期も重なってか，近 年とくに，シミュレータを用いた教育の必要性が示 唆されるようになった。本セッションでは，これか ら行われるすべてのセッションの導入として, 高機 能患者シミュレータ (High Fidelity Human Patient Simulator)である, METI (Medical Education Technologies Inc.) 社の患者シミュレータについて, その特徴を知っていただくものである.

1. 日本における高機能患者シミュレータ

高機能患者シミュレータが日本に紹介され約 10
年が経った。初期においていち早く導入したのは, 九州大学および浜松医科大学であった。

九州大学で導入されたシミュレータは, CAELink社とスタンフォード大学の D.M. Gaba M.D., ワシントン大学の H. Schwid M.D.らの共同開発によ るものである。浜松医科大学で導入されたシミュレー 夕はLoral Data System社とフロリダ大学のS. Lampotang Ph.D., J.S. Gravenstein M.D., M.L. Good M.D. らの共同開発によるものである。

CAE-Link社およびLoral Data System社はそれ ぞれCAE社およびLoral社を母体として持ってい た。CAE社とLoral社は，それぞれ航空機やロケッ ト，人工衛星などのシミュレータの製作を行ってい るメーカーである。
*アイ・エム・アイ株式会社

商品・市場開発部救急・教育チーム
著者連絡先 島崎康司

早 343-0824 越谷市流通団地 3-3-12 アイ・エム・アイ株式会社 商品・市場開発部救急・教育チーム 
その後, CAE-Link社の患者シミュレータ部門は イスラエルの MedSim-Advanced Medical Simulations社に移るが，まもなく開発および生産が ストップした。 また, Loral Data System社の患者 シミュレータ部門は, METI社として独立し, 現在 に至っている.

\section{METI社製高機能患者シミュレータの種類}

METI社の患者シミュレータについては，2003年 11 月現在, HPS 患者シミュレータ, HSS ルルサ イエンスシミュレータ，PediaSim小児用マネキン， ECS 救急ケアシミュレータが存在する。また，軍関 係で使用されている CTPS (Combat Trauma Patient Simulator）というシミュレータも存在する.

HPS 患者シミュレータは, 麻酔科で使用するため の麻酔練習用のシミュレータとして開発され, 麻酔 の導入および維持覚醒についての流れを患者に行う がごとくシミュレータで経験させるものとして使用 されている。 さらに上級の教育トレーニングとして, 麻酔中に起きる可能性のある危機的イベントをシミュ レーションし, 患者観察方法, モニ夕監視方法, 対 処方法などを経験させるものとして使用されている.

このため, HPS 患者シミュレータでは, より臨床 に近い状態で教育ができるように, 汎用の生体情報 モニタにバイタルサインを表示させることができ る。また，シミュレータのマネキンに対して，バッ グ換気や挿管などの手技, 特殊ガスである揮発性麻 酔薬の使用や，バーコードを使用した薬剤の投与, さらには筋刺激に対する反応などをみることができ るように開発された。

その後, 呼吸療法士など麻酔科領域以外からの需 要が増えてくることとなる. METI社は, HPS患者 シミュレータから, おもに麻酔科のみが必要として いる機能を省きHSSヘルスサイエンスシミュレータ としてリリースした。肺機能や呼気ガス生成機能な ど呼吸器系において精密なシミュレーションが可能 であった HPS 患者シミュレータは, 呼吸療法士の トレーニングにも向いていたのである.
また，METI社は，大人のシミュレーションだけ でなく，小児のシミュレーションを可能にするため 小児の生理学モデルを開発し，小児用マネキンとと もにリリースした。この小児のシミュレータも HPS 患者シミュレータと同様に, 揮発性麻酔薬を実際に 使用したシミュレーションが可能である.

ECS 救急ケアシミュレータは, 救急領域のトレー ニング(ACLSやATLS)の需要が高まってきたこと から, 心肺蘇生や, 外傷処置などについて, 場所を 選ばずにトレーニングができるようにモバイルシミュ レータとして開発された。ソフトウェアは, 生理学 モデルおよび薬理学モデルを搭載した上位機種と同 じである。

\section{METI社製HPS患者シミュレータの特徵}

METI社の患者シミュレータの大きな特徵は, 患 者シミュレータの動作が, 循環, 呼吸, 代謝, 筋弛 緩についての生理学モデルと薬理学(薬力学と薬物 動態学) モデルにより, バイタルサインが恒常性が 保たれるように自動的に変動するところにある．多 くのマネキントレーナがプラカード型(プラカード に心拍数，血圧，呼吸数などをトレーナーが逐一記 入し提示しながらトレーニングを行う方法)の延長 であることを考えると，高機能なシミュレータであ ることがわかる.

\section{HPS 患者シミュレータの構成}

METI社製HPS 患者シミュレータは，おもに以下 の3つのユニットから構成される.

第1のユニットは，全身の人体モデル(マネキン) である。このマネキンは，聴診や触診，人工呼吸や 薬剤投与などの処置ができる受講者のインターフェー スとなる。

第 2 のユニットは, 操作用 PCである.オペレー 夕またはトレーナーが, シミュレータの操作を行う ためのユーザーインターフェースを有する。また， 生理学, 薬理学の高度な計算も行われている.

第3のユニットは，各種シミュレータの集合体で あるラックである。このラックには，吸気ガス測定 
ユニットや呼気ガス生成ユニット, 心電図, 血圧波 形，呼吸などをシミュレートする各種ユニットが収 められている。これらのユニットは, 操作用 PCに より常に制御されている.

このようにユニットがそれぞれ独立しているの で，ユニットごとに細かな変更が可能であるという 特徵がある。ハードウェアのタイプについては，初期 のものとして日本に導入された Type B というものが ある.この後, ユニットが変更され Type C.0, Type C.1, Type C.2を経て現在Type Dに至っている.

この 10 年に至るまでに, 医学教育現場からの要 望に応じて, 細かい変更がなされてきた。これは, 医療技術の進歩と, 医療器械の多様化, 教育内容の 変化によってシミュレーションされる内容自体も変 化してきたためである。

\section{5. デモンストレーション}

実際にどのように動作するのか HPS 患者シミュ レータを用いての麻酔の導入, 維持, 覚醒のデモン ストレーションを以下に述べる。

・意識があり，自発呼吸をしている患者さんは， 目に光を当てると対光反射を示し，頸動脈など 12 力 所で脈が触れることがわかる，聴診器を用いて呼吸 音や心音を聞くことも可能である，循環モニ夕，呼 気ガスモニ夕を患者さんに接続する。プロポフォー ルを使って導入を試みる。まもなく目を閉じ意識が なくなったことがわかる。しばらくすると呼吸も浅 くなり, 心拍数, 血圧とも下がり始めてきた。筋刺 激装置で TOFの刺激を加えると，4回反応が返って くる。べクロニウムを投与し，浅い呼吸で放置をし てみると $\mathrm{SpO}_{2}$ が下がり始めてくる. $100 \%$ の酸素で 補助換気を行うと，まもなく $\mathrm{SpO}_{2}$ が上がり始める. 酸素が肺胞から血中に拡散するところもシミュレー ションしている，TOFに対する反応にフェードが 現われ，しばらくすると刺激に対する反応が完全に なくなる，補助換気をやめると，患者さんの呼吸は すでに停止している．プロポフォールを追加投与し
た後，挿管し，用手換気を続ける，瞳孔を観察する とピンホールになっている。用手換気から，機械換 気に切り替える。換気量などに気をつけながら， PCV モードで使用する。しばらくすると，カプノグ ラムが再呼吸を示しているのに気づいた。先ほどま で無色だったアブゾーバーが紫色に変色している. 古いアブゾーバーを使用していたことが原因だった。

ここまでからもわかるように，実際に患者さんに 使用する機器をマネキンに対して使用できること は，非常に有意義であることがわかる，また，さま ざまな反応が同時進行で起こっていることもわか る.これらすべての反応を同時にオペレータが操作 しているわけではない. 生理学モデルまた薬理学モ デルが代わって行っているのである。オペレータが 操作するときは, 生理学モデルから逸脱した反応や, 症状を表現させるときである.

\section{6. 設置とシミュレーションスペースの考え}

現在, 高機能患者シミュレータであろうと, パー トタスクマネキンであろうと, その設置場所や設備, 使用環境が大きな問題になっている.

これは，今までシミュレータを使用した教育とい うものが一般的ではなかったため大きな問題として 扱われなかったことが要因と考えられる。しかし， 今後シミュレータを用いた教育が重要な位置を占め ていくであろうことを考えれば，設置場所や設備， 使用環境については，解決しなければならない問題 である。

スペースについては，1)シミュレータと付属設備 のためのスペース，(2)シミュレータに使用する機器 のためのスペース，(3)レーナーも含めた 1 回に行 う講義の受講者の人数(4)講義内容およびその方法, などにより，シミュレーションスペース(作業場) と， 部屋全体のスペースが決定される。

HPS/HSS/PediaSim を使用し, 受講者5名, イン ストラクター1名(オペレータ1名)で, シミュレー 夕を使用したシミュレーションのみを行うとして， 
$25 \mathrm{~m}^{2}$ 以上を推奨する。同様の条件で, ECS 患者シ ミュレータでは $20 \mathrm{~m}^{2}$ 以上を推奨する.

最近は, シミュレーション室, シミュレーション ラボ，臨床実習室など，さまざまな呼び名でシミュ レーション教育専用のスペースを確保する施設が 徐々にではあるが増加している.

海外のシミュレー夕を使用している施設がそうで あるように，そのようなスペースをホームページ上 などで公開することも問題解決の一つになるのでは ないかと考える。

\section{7. まとめ}

METI社のHPS，HSS，PediaSim，ECS それぞれ の患者シミュレータの生理学モデルは生体恒常性を 保つようにプログラミングされている，METI社の HPS 患者シミュレータは, 患者に使用している生体 情報モニタや人工呼吸器, 麻酔器, 除細動器などを そのまま用いることのできるマネキンを有し, 心音, 呼吸音の聴診や脈拍の触診, 意識の確認などもでき るシミュレータである.

シミュレータなどの設置や運用について問題点も 指摘されている。シミュレー夕を使用した教育が一 般化することは必至であるため, 解決を図らなくて はならない重要課題である.

\section{HPS FOR INTERMEDIATE}

このセッションでは, 高機能患者シミュレータで ある METI社の HPS 患者シミュレータを使用した 経験がある方, およびHPS FOR BEGINNER参加 者を対象とし，教育内容(シミュレーション内容)に 従って, 実際に患者やシナリオを作成することを目 的とする.

まず，HPS患者シミュレータのソフトウェアにつ いての基本知識と, その動作についての考え方, 重要 な患者パラメー夕の種類と設定について説明する.

次に患者の作成方法を解説した後, いくつかの患 者を作成する．シナリオについても同様に，シナリ オの意味と HPS 患者シミュレータでのシナリオの構
成と作成方法を説明する.

最後に, シミュレーション方法について説明する.

\section{HPSソフトウェアについて}

HPS 患者シミュレータを含め, HSS ルスサイエ ンスシミュレータ，PediaSim小児用マネキン， ECS 救急ケアシミュレータのすべては，同じソフトウェ アを使用している(ただし，ハードウェアの機能上， 使用不可能なパラメータが一部存在する).

METI社の患者シミュレータは, 生理学モデルと 薬理学モデルに従ってバイタルサインが自動計算さ れている。自動計算されるバイタルサインは，循環 器系では, 心拍数, 動脈血圧, 中心静脈圧, 肺動脈 圧, 心拍出量, 虚血の度合いなどで, 呼吸器系につ いては, 一回換気量, 呼吸数, 血中ガス分圧(酸素, 二酸化炭素, 吸入麻酔薬), 動脈血酸素飽和度など である。そして，これらに影響を与える因子として 約 80 種類の患者パラメータが存在する.

\section{2. 患者パラメータ}

METI社の患者シミュレータで設定可能なパラメー 夕は，表1に示すようなカテゴリーに分かれている.

それぞれのカテゴリーで，以下に示すような患者 パラメータが設定できるようになっている.

(1)コンディションでは, 意識, 筋弛緩状態, 心音, 呼吸音，体重，気胸や心タンポナーデなどの設定が 可能である.

(2)薬剤では，麻薬・鎮痛薬，鎮静薬，筋弛緩薬， 拮抗薬，心血管作動薬など約 60 種類の薬剤の投与設 定が可能である.

\section{表1 患者パラメータ}

(1)コンディション アセスメントハラウマ (2)薬剤 (3)体液

麻薬・鎮痛薬/鎮静薬/筋弛緩薬/拮抗薬/心血管作動薬

(4)心血管

(5)呼吸

$$
\text { カテーテル/体外刺激/心/血管 }
$$

エアウェイ/肺機能/呼吸のコントロール 
(3)体液では, 尿量, 出血, 輸血などの設定が可能 である。

(4)心血管では, カテーテルの位置や，除細動器や 体外式ペースメーカーの設定が可能である。このほ かに, 心拍数や心筋の収縮力, 虚血, 不整脈など心 臓に関するものや，バロレセプター，各種血管の抵 抗や，静脈還流などの血管に関する設定などが可能 である。

(5)呼吸では，舌浮腫や喉頭痙攣など挿管困難状態 や，気管支閉塞を含めた抵抗，肺のコンプライアン スなどの設定が可能である。また，肺胞内のガス分 圧，シャント率，酸素消費量，呼吸商，一回換気量， 呼吸回数などの設定が可能である.

上記の患者パラメータは一部であるが，患者パラ メータのほとんどは, バイタルサインそのものを決定 するというよりは，バイタルサインを決定するため の生理学モデルの因子(係数)を操作することになる.

\section{3. 患者の作成・患者パラメータの設定と注意}

METI社の患者シミュレータでは，上述したカテ ゴリーに分けられた患者パラメー夕を変更すること で, 循環器系, 呼吸器系の病態が作られる。そして, 患者パラメータを変更して作られた病態をもとに， シミュレータは回復する方向に自動計算し，バイタ ルサインに現われる。しかし，その均衡が崩れてし まうと症状は自動的に悪化する.

METI社の患者シミュレータの患者パラメータを 設定するには大きく 3 種類の方法がある。それぞれ のパラメータ設定の特徴についてみてみる.

第 1 の設定方法として，Fixed 患者パラメータが ある。例えば，Fixed Heart Rate という患者パラメー 夕があるが，このパラメータでは，心拍数を 110 回· $\mathrm{min}^{-1}$ と直接決定できる. しかし，この方法で決 定された值については, 心拍数の設定值が固定 (Fixed) されてしまっているので, 生理学モデルに 従った心拍数の変動はみられなくなる。また，薬剤 を投与したときの心拍に対する反応もなくなり，心 拍数に影響する薬剤をいくら与えても，110回・ $\mathrm{min}^{-1}$
が表示され続ける。この方法は，プラカードに心拍 数 110 回・ $\min ^{-1}$ と書いて現在の状態を提示するのと 同じことを，コンピュータ上で行って生体情報モニ 夕に表示させているのである.

第2の設定方法として，Factor 患者パラメータが ある。例えば，Heart Rate Factor という患者パラ メータがあるが，このパラメータでは，心拍数を現 在あるべき状態に対して係数(Factor)を乗ずる方法 で決定することとなる。この方法で決定された心拍 数については，前述した固定(Fixed)された值とは 異なり，生理学モデルによって得られた計算值が適 応される。ただし，得られた計算值に係数を乗じた 值が最終的な值となる。このことは，薬剤を投与し たときについても同じことがいえる。薬物動態学と 薬力学から得られた反応についても係数が適応され て最終的な值として決定される。このようにFactor 患者パラメー夕を用いた場合, 生理学モデルおよび 薬理学モデルが適応されることになる.

第 3 の設定方法として，Override 患者パラメータ がある。その名のとおり，現在ある状態に上書きす るような動作を行う設定方法である。例えば， Cardiac rhythm override という患者パラメータが あるが，このパラメータは，おもにECGの波形に ついて整脈および不整脈を，現在の状態に対し強制 的に上書きするものである，ECGについては，生理 学モデルに従った心筋の状態により, Sinus, PVC, ST 変化, VT, VF, Asystoleなどの発生が決定さ れているが，Cardiac rhythm overrideで不整脈を 設定すると，現在の状態に強制的に上書きされて設 定した不整脈が表示され，各種バイタルサインもこ れに従って変動することとなる。

シミュレーションする内容や受講者のレベルによつ て, どのような設定方法を選択するかが重要なポイ ントとなる.

\section{4. 患者の作成}

METI社の患者シミュレータには，新規に患者を 作成し，保存する機能が備わっている．また，シミュ 


\section{表 2 患者の作成手順例}

(1)既往歴の決定

(2)ターゲットとなるバイタルサインの決定

(3)症状を患者パラメータにあてはめる

(4)患者パラメータの設定

(5)患者パラメータの調整

(6)保存

レーション途中の患者状態を保存する機能も備わつ ている。これらの機能により，例えば，異なる循環 動態や呼吸動態を示す患者に対し，それぞれに適し た麻酔方法を考え実施させるというシミュレーショ ンが可能である。 また，あるところまで処置を行っ た患者を別のスタッフに引継ぎ(コミュニケーショ ン)，処置を再開するというシミュレーションも可 能である。

METI社の患者シミュレータで患者を作成する手 順を，表2に一例として提示する。

METI社の患者シミュレータで新規の患者を作成 するためのポイントがいくつか存在するので, 表 2 に示した項目別に補足する.

(1)既往歴は, 患者の大きな特徵を表わすものであ り，シナリオの伏線としても重要な項目である.

(2)患者のバイタルサインの決定については, METI社の患者シミュレータの場合, 生理学モデル に従ってバイタルサインが自動的に決定されるとい う特徴から，あくまでもターゲットを設定すること になる。

(3)ここで重要なのは, 心拍数, 血圧, 呼吸数など を直接患者パラメー夕にあてはめることではない. 例 えば， $\mathrm{SpO}_{2}$ を 88 \%にする患者パラメータをあては めるのではなく, 酸素化しづらい要因となる患者パ ラメータをあてはめることになる。

(4)(5)実際に患者パラメータをシミュレータの操作 用 PCで設定し，シミュレータのバイタルサインや 動作がどのように変動するか確認し, 最終的な患者 パラメータの調整を行うことになる.

\section{5. 循環と肺機能の悪い患者の作成}

まず，高血圧で心筋虚血になりやすい状態を作成
する，循環器系パラメー夕の設定は，平均血圧を一 定範囲で収める Baroreceptor Max (Min) Pressure を高めに設定することで，血圧が高くなり，心拍数 が速くなる，また，虚血の進行度を決定する Ischemic Index Averaging というパラメー夕を設定すること で心筋に対する酸素の需要と供給のバランスを変更 する。これで，高血圧で心筋虚血になりやすい状態 になった。

次に肺機能の悪い状態を作成する。呼吸器系のパ ラメー夕設定は，気管支の抵抗の程度を決定する Bronchial Resistanceを高めに設定し，肺機能の低 下を表現するための Shunt Fractionを高めに， Lung Complianceを低涪設定する。呼吸音に Rale やWheezing を設定すると，呼吸音聴診時に設定さ れた音が聞ける。

このように循環器系と呼吸器系の一部のパラメー 夕を変更すると，その後の心拍数や血圧， $\mathrm{SpO}_{2}$, 一 回換気量, 呼吸回数の変動や虚血による ECG 変化 などは，すべてコンピュータが計算し，自動的にバ イタルサインが変化していく.

\section{6. 薬㨈の反応が異なる患者の作成}

薬剤反応に違いのある患者の作成については，患 者の体重を変更することによって異なる薬剤反応が 示される．また，Baroreceptor Gainというパラメー 夕を設定することで， Baroreceptor の反応の強さを 設定できるので，特に心血管作動薬について，異な る薬剤反応が示されることになる。

\section{7. 問題：患者作成}

100 メートル全力疾走後, 胸を押さえ倒れ込んだ 患者が運ばれてきた…このような患者の作成はど のように行ったらよいか？

まず，酸素消費量を高く設定し，筋弛緩を $100 \%$ に設定することで，無酸素運動の状態を作り出す. そのまま変化をみていくと, 体内の酸素濃度は急激 に低下し，二酸化炭素濃度が上昇していく，虚血が 進行し, ECGにST変化がみられる。この時点で, 筋弛緩状態を解除し, 患者を保存する。 
作成した患者を動かしてみる。息を切らせ, 虚血 になった患者になっている. 高濃度の酸素を与える と, 心拍, $\mathrm{SpO}_{2}$, 一回換気量, 呼吸回数などが徐々 に回復していくのが観察される.

患者の作成で注意することは, Fixed Heart Rate など，固定した值を決定するパラメー夕はどのよう な処置に対しても反応しなくなるので, 極力使用し ないことである。

\section{8. シナリオの作成}

METI社の患者シミュレータのシナリオ (Scenario) は, 複数の状態 (States) から構成されている。これ らのStateを選択していくことにより，シナリオが 進行していく.

一つのStateは，そのときに起こる事柄(Events) と移動条件(Transitions) から構成される. Eventに は，複数の患者パラメータを設定することができ， この患者パラメータの組み合わせにより, 患者状態 (病態)を作り出すことになる。 また, Transitionに は, 複数の移動条件を設定することができ, この条 件をトリガーとして別の State に自動で移ることも 可能である.

METI社の患者シミュレータでシナリオを作成す る手順を, 表了に一例として提示する.

METI社の患者シミュレータで新規の患者を作成 するためのポイントがいくつか存在するので, 表3 に示した項目別に補足する.

(1)教育内容および対象者の決定は, 非常に重要で ある。 なぜなら, 同様の教育内容であっても, 対象 者が異なると, シミュレーション方法がまったく異 なる場合もあるからである。これは，(3)のナリオ のキーポイントについても同様である。この例は, 次のシミュレーション方法で示す。(4)の患者プロファ イルと現状の設定については, シナリオの伏線のた めにも，また，シミュレーションにリアリティーをも たせるためにも，これらを考慮した内容にすべきで ある. (5)使用可能な薬剤, 機材, モニタリングパ ラメータについては，教育内容を考慮したものにす

\section{表3 シナリオ作成の手順例}

(1)教育内容, 対象者の決定

(2)シナリオで発生するイベントの決定

(3)シナリオのキーポイントの決定

(4)患者プロファイルとシミュレーション開始時の状態

(5)使用可能な薬荗, 機材, モニタリングパラメータ

(6)シリオの流れのスケッチ

(7)フローチャートの作成

8シナリオの作成と患者シミュレータの動作確認

9)シナリオの調整

(10保存

る必要がある，場合によっては，トラップとして使 用するような薬剤などが必要かもしれない.

(6)および(7)については, 操作用 PCでシナリオを 作成するときのガイドラインとなるものである，図 1〜図4で，上記のシナリオの作成法に従った例を 示す.

\section{9. シミュレーション方法}

同じシナリオを使用した教育でも，対象により， シミュレーション方法を変更した方が効果的な場合 がある，例えば学生と研修医で，先ほど作成したよ うなシナリオについてシミュレーションしたとす る．補液の優先度が高いことを教えたい場合，学生 に対しては, 補液以外の処置に対する反応を起こさ ないようなシミュレーション方法を採用する必要が あるかもしれない。この場合, 病態を発生させる State と回復させるStateを作成しておいて，受講者 が正しい処置を口頭で指示したときのみ，トレーナー が手動で回復するStateへ変更する。研修医に対し ては，どのような処置でも反応するようなシミュレー ション方法を採用する必要があるかもしれない。も ちろんこの場合，回復させる State は使用しても使 用しなくてもよい，処置を受講者に任せることによ り，誤った処置をした場合には，症状が自動的に悪 化するのが観察できる.

METI社製HPS 患者シミュレータは，処置として おもに吸入ガス濃度(換気量や呼吸回数を含む) や薬 剂投与，除細動，胸腔穿刺や胸腔ドレナージ，心囊 穿刺などに自動的に反応するので，これらの項目を 


\begin{tabular}{|c|}
\hline (1)教育内容, 対象者の決定 \\
\hline $\begin{array}{l}\text { 内容：ショックの診断(脱水) と低酸素時の処置 } \\
\text { 対象：研修医 (医学生) }\end{array}$ \\
\hline (2)シナリオで発生するイベント \\
\hline $\begin{array}{l}\text { • 低酸素 } \\
\text { ・心筋虚血 } \\
\text { ・脱水 }\end{array}$ \\
\hline (3)シナリオのキーポイント \\
\hline $\begin{array}{l}\text { ・酸素投与と補助換気ができるか } \\
\text { ・ECGが読めるか (ST変化, 心室性期外収縮など }) \\
\text { ・血圧を測定し, ショックであることがわかるか } \\
\text { ・補液の指示ができるか }\end{array}$ \\
\hline
\end{tabular}

図 1 シナリオ例(教育内容/対象者, 発生イベント, キーポイント)

\section{(4)患者プロファイルとシミュレーション開始時の状態}

「100メートル全力疾走後胸痛で倒れた」患者を使用

男性. 身長 $170 \mathrm{~cm}$. 体重 $55 \mathrm{~kg}$ 前後の瘦せ型. 高校 1 年. 野球部 (運動は得意では ない).

グラウンドで走り込み中に倒れる. 3 日間の合宿3日目の出来事. 合宿当日から下痢など体調不良だった。

(5)使用可能な機材，モニタリングパラメータ，薬剂 $\mathrm{ECG}, \mathrm{SpO}_{2}$, 非観血的血圧計 (NIBP). その他の薬剤や機材は順次口頭で指示.

(6)シナリオの流れのスケッチ

日曜の午後 1 時, 当直医として受講者 1 名. 看護師は 3 名いるが, 1 名のみサポー 卜可能.

部活中に気を失った高校 1 年生男子野球部員が搬送されてきた.

付き添いは 3 年生. 自主練習での出来事, 付き添いの部員に様子を尋ねるが要領 を得ない.

$\mathrm{ECG}, \mathrm{SpO}_{2}, \mathrm{NIBP}$ を接続することで，頻脈とST下降が観察される. $\mathrm{SpO}_{2}$ は低 く，呼吸は浅い. NIBPも低い值を示す．対光反射はあり． $100 \%$ 酸素で補助換気し補液を行い, 経過を観察する.

図2 シナリオ例(患者プロファイル, 使用機材他, スケッチ)

取り入れることでインパクトのあるシミュレーショ ンができる.

シミュレーション終了後に必ずレビューを行うこ とで, トレーニングの内容を再確認することができ
る。VTRでトレーニングを撮影したり，接続して いる生体情報モニ夕の機能を使用してトレンドデー 夕を振り返るのも一つの方法である. 
(7)フローチャートの作成

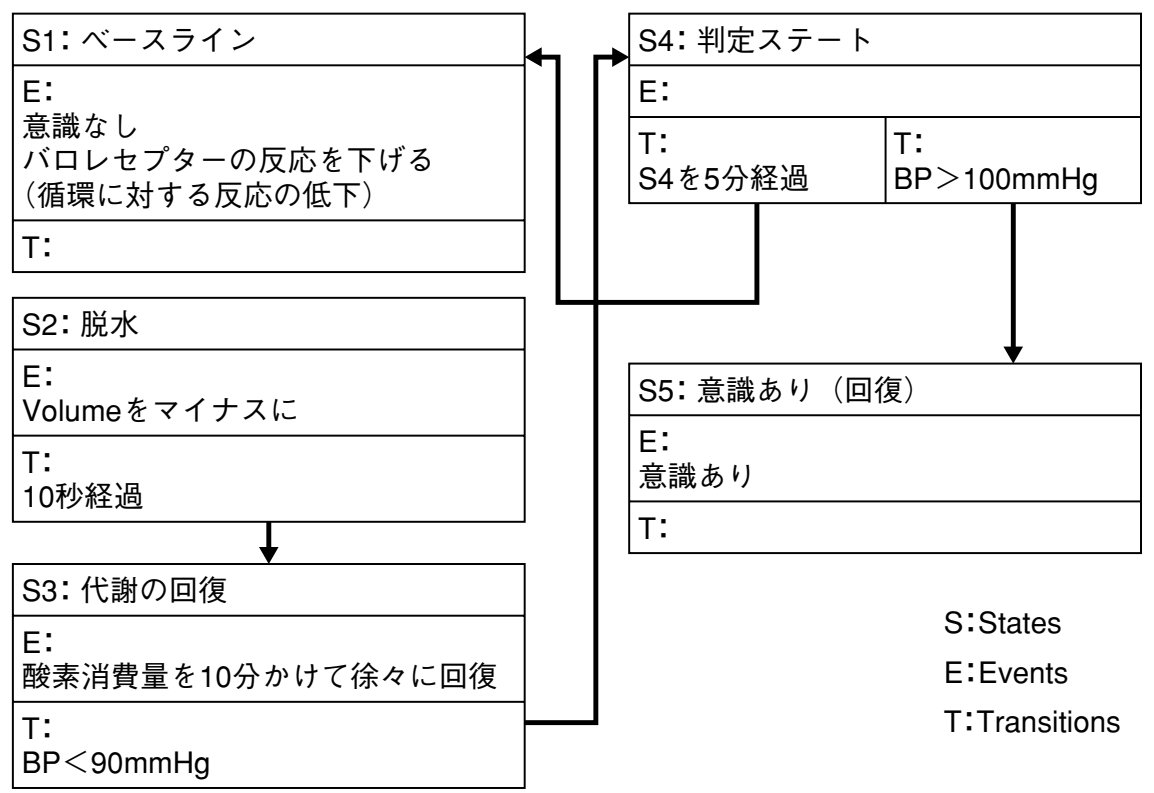

図3 シナリオ例(フローチャート)

\begin{tabular}{|c|c|c|}
\hline State & Vital Sign & Action \\
\hline $\begin{array}{l}\text { S1： } \\
\text { ベースライン }\end{array}$ & $\begin{array}{l}\mathrm{HR}=\text { 頻拍 } \\
\mathrm{BP}=\text { 正常 } \\
\mathrm{SpO}_{2}=\text { 低下 } \\
\mathrm{RR}=\text { 頻呼吸 } \\
\text { 意識なし } \\
\text { バロレセプター } \\
\text { の反応低下 } \\
\end{array}$ & $\begin{array}{l}\text { ・100メートル全力疾走後胸痛で倒れた患者を使用 } \\
\text { ・準備ができたら脱水のS2 選択 } \\
\text { ・意識なし } \\
\text { ・循環に対する反応が低下している }\end{array}$ \\
\hline $\begin{array}{l}\text { S2： } \\
\text { 脱水 }\end{array}$ & $\begin{array}{l}\mathrm{BP}=\text { 低下 } \\
\text { 各種処置に応じ } \\
\text { る }\end{array}$ & $\begin{array}{l}\text { ・モニタを適切に接続できるか } \\
\text { ・脈拍, 血圧を測定し, ショックであることがわかるか } \\
\text { ・呼吸状態, } \mathrm{SpO}_{2} \text { 測定により低酸素であることがわかるか } \\
\text { ・酸素投与ができるか }\end{array}$ \\
\hline $\begin{array}{l}\text { S3: } \\
\text { 代謝の回復 }\end{array}$ & $\begin{array}{l}\text { 酸素消費量の回 } \\
\text { 復 } \\
\text { 各種処置に応じ } \\
\text { る } \\
\end{array}$ & $\begin{array}{l}\text { ・徐々に代謝が回復していく } \\
\text { ・脈拍, 血圧を測定し, ショックであることがわかるか } \\
\text { ・呼吸状態, } \mathrm{SpO}_{2} \text { 測定により低酸素であることがわかるか } \\
\text { ・酸素投与ができるか }\end{array}$ \\
\hline $\begin{array}{l}\text { S4： } \\
\text { 判定ステート }\end{array}$ & & 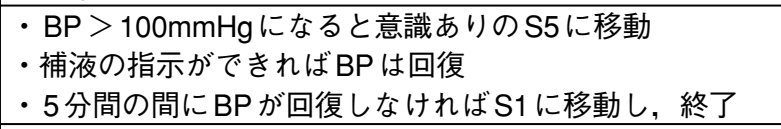 \\
\hline $\begin{array}{l}\text { S5： } \\
\text { 意識あり }\end{array}$ & 意識の回復 & \\
\hline
\end{tabular}

図4 シナリオ例(トレーナー, 操作者用ノート)

最後に

今後, 卒前教育や卒後臨床研修, 危機管理などの 院内教育などで，シミュレータを使用した教育が重
要な位置を占めていくことは間違いない. 今回, リ アルタイムに数多くのバイタルサインが自動変動す る高機能患者シミュレータを使用して, 患者やシナ リオを作成した。高機能患者シミュレータである 
METI社の患者シミュレータで作成された患者やシ ナリオは, 同じ症状であっても毎回違ったバイタル サインを示す，症状の回復についても，処置のタイ ミングや組み合わせにより, 回復の過程が毎回異な る反応を示す。つまり, 同じ内容のシミュレーショ ンであっても, 毎回新鮮なシミュレーションを可能 にしているのが, 生理学モデルと薬理学モデルをも つ高機能患者シミュレータである.

シミュレータを使用した医学領域の教育や研究は 始まったばかりであるが, 高機能患者シミュレータ を使用することで現実感と緊張感を併せもった教育 ができることを期待する.

〔付録〕

以下に海外の患者シミュレータ使用施設につい て, 個人的にとくに目についたホームページのアドレ スを揭載する. 設置スペース, 使用機材, シミュレー ション内容など参考にしていただければと考える (2004年 8 月現在).

\section{Baylor College of Medicine,} Houston Center for Advanced Patient Simulation http://anesnet.anes.bcm.tmc.edu/script/simulator.asp

\section{Cincinnati Children's Hospital Medical Center}

http://www.cincinnatichildrens.org/svc/prog/ems/ human-simulator.htm

\section{Mount Sinai School of Medicine}

http://www.mssm.edu/anesthesiology/virtual_tour/ humansim.shtml

\section{Stanford University}

http://anesthesia.stanford.edu/VASimulator/simulator. htm

\section{UCLA}

http://www.anes.ucla.edu/dept/simulator.html http://www.anes.ucla.edu/dept/simulatorbrochure. pdf

\section{University of Florida}

http://www.mbi.ufl.edu/facilities/hps.php

http://www.mbi.ufl.edu/facilities/sims.php

\section{University of Rochester Medical Center}

http://web.anes.rochester.edu/simulate/simcent.htm 


\title{
HPS FOR BEGINNER/HPS FOR INTERMEDIATE
}

\author{
Koji SHIMAZAKI
}

IMI Co., Ltd.

Human Patient Simulator (HPS) family and Emergency Care Simulator (ECS), both manufactured by Medical Education Technologies Inc., (METI), are very unique model-driven high fidelity patient simulators in the world. We arranged two presentations, HPS FOR BEGINNER and HPS FOR INTERMEDIATE, for these workshops.

HPS FOR BEGINNER : It contains a history of HPS \& ECS, an overview of unique hardware \& software, and a training \& simulation area with HPS \& ECS. And hands-on demonstration covers the use of HPS with a real patient monitor and a real anesthesia machine.

HPS FOR INTERMEDIATE : It contains an HPS movement according to physiology \& pharmacology models, philosophy of patients \& scenarios \& training with HPS family \& ECS. And hands-on also cover new patient and new scenario developing technique \& operating technique with these created patient \& scenario.

Key Words : HPS, ECS, Model driven simulator

The Journal of Japan Society for Clinical Anesthesia Vol. 24 No.7, 2004 